\title{
Isolation, Characterization and Antimicrobial Resistance Patterns of Lactose-Fermenter Enterobacteriaceae Isolates from Clinical and Environmental Samples
}

\author{
Israa Abdul Jabbar Ibrahim*, Tuqa Abdul Kareem Hameed \\ Department of Biology, College of Education for Pure Science Ibn Al-Haitham, University of Baghdad, Baghdad, Iraq

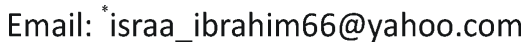

Received 20 September 2015; accepted 23 November 2015; published 26 November 2015

Copyright (C) 2015 by authors and Scientific Research Publishing Inc.

This work is licensed under the Creative Commons Attribution International License (CC BY). http://creativecommons.org/licenses/by/4.0/

\section{(c) (i) Open Access}

\begin{abstract}
The lactose-fermenter Enterobacteriaceae are the most frequent cause of clinical infection in our country. The objective of this study was to isolate and identify the most common lactose-fermenter Enterobacteriaceae from clinical samples, including urine, blood, wounds, and sputum, obtained from the local hospital and from environmental samples from a chicken farm, agriculture soil, and water from the Tigris River in Baghdad City. The study also aimed at establishing the antibiotic resistance patterns of the isolated bacteria. A total of $\mathbf{1 5 5}$ bacterial isolates were identified from 10 genera according to the Vitek 2 system. The most common bacterial isolates from the clinical and environmental samples were Escherichia coli and Klebsiella pneumoniae, respectively. The antibiotic resistance patterns showed that all clinical and environmental isolates were multidrug resistant to $\beta$-lactam (except carbapenems) drug and aminoglycosides and more sensitive to carbapenems.
\end{abstract}

\section{Keywords}

Enterobacteriaceae, Lactose Fermenters, Clinical, Environmental Samples

\section{Introduction}

Enterobacteriaceae are distributed worldwide. They are found in soil, water, fruits, meats, eggs, vegetables,

${ }^{*}$ Corresponding author.

How to cite this paper: Ibrahim, I.A.J. and Hameed, T.A.K. (2015) Isolation, Characterization and Antimicrobial Resistance Patterns of Lactose-Fermenter Enterobacteriaceae Isolates from Clinical and Environmental Samples. Open Journal of Medical Microbiology, 5, 169-176. http://dx.doi.org/10.4236/ojmm.2015.54021 
grains, flowering plants and trees, and in animals from insects to man [1]. Enterobacteriaceae are Gram-negative rods with a length of $1-3 \mu \mathrm{m}$. They are facultative anaerobes, oxidase-negative, catalase positive, and grow on MacConkey agar, and their natural hosts are human and animal intestines [2]. There are 44 genera and approximately 176 species [1]. The normal flora include Escherichia coli, Enterobacter spp., Klebsiella spp., Morganella spp., Proteus spp., Providencia spp., and Serratia spp., and the obligate human pathogens include Salmonella spp., Shigella spp. and Yersinia spp. [3]. Enterobacteriaceae may account for $80 \%$ of clinically significant isolates of Gram-negative bacilli and 50\% of clinically significant bacteria in clinical microbiology [4]. Some Enterobacteriaceae species have only been identified based on their16S rDNA sequence and have not been isolated or characterized biochemically [1].

The Enterobacteriaceae family is divided into three groups on the basis of lactose fermenter as follows: I-lactose fermenters, such as Escherichia coli, Enterobacter spp., and Klebsiella spp.; II-late lactose fermenters, such as Citrobacter spp. and Serratia spp.; and III-lactose nonfermenter, such as Edwardsiellatarda, Hafnia, Morganella morganii, Proteus spp., Providencia spp., Salmonella spp., Shigella spp., and Yersinia spp. [2] [5]. Common water microbiological indicators are used as markers of risk to human health, including total coliform, Escherichia coli, enterococci, Clostridium perfringens, and Pseudomonas aeruginosa [6] [7]. Vegetable contamination can arise due to the treatment of soil with organic fertilizers, such as sewage sludge and irrigation water, as well as from the ability of pathogens to persist and proliferate in vegetables [8] [9]. E. coli is one of the common normal floras (N.F.) of the gastrointestinal tract of poultry and humans. It is also present in other animals but some strains that pathogenic to both poultry and humans [3] [10].

Pathogenic Gram-negative bacteria are treated with antibiotics, and the efficient agents are fluoroquinolones, beta-lactams and aminoglycosides [11]. Resistant strains from the poultry gut readily contaminate poultry carcasses, and when consumed, they alter or affect the endogenous normal flora of humans [12]. Gene transfer occurs primarily in vivo between gastrointestinal tract bacteria (N.F.) and pathogenic bacteria because identical resistant genes are present in diverse bacterial species from different hosts [13]. The objective of this study was to determine the incidence isolates and antimicrobial resistance of lactose fermenter Enterobacteriaceae from clinical and environmental specimens.

\section{Methodology}

\subsection{Specimens}

In this study, 165 clinical and environmental samples were collected from different sources in Baghdad City. Samples collection was performed from $1^{\text {st }}$ September 2014 to $1^{\text {st }}$ February 2015.

\subsection{Clinical Specimens}

A total of 93 clinical isolates were evaluated in this study. The isolates were obtained from Ibn Al Balady Hospital, Imam Ali Hospital, Al Kindy Educational Hospital, Educational Laboratory of The Medical City and Al-Shaheed Al-Sader Hospital in Baghdad City. The strains were isolated from urine, sputum, blood, and wounds. A total of 74 urine specimens, eight sputum specimens, four blood specimens, and seven wound swabs were analyzed. Eosin methylene blue (EMB) agar and MacConkey agar were used to isolate the enteric bacteria. The plates were incubated for 24 hours at $37^{\circ} \mathrm{C}$ [2].

\subsection{Environmental Specimens}

A total of 72 environmental specimens were collected, including 27 chicken feces, 25river water samples (Shawaka Area of the Tigris River), and 20 agriculture soils.

\subsection{Collection of Water Specimens}

Twenty-five water samples were obtained weekly from the Shawaka area of the Tigris River in Baghdad city. The samples were collected in duplicate from the water surface into sterile 1-L glass bottles at 8:00 am and transported to the laboratory in an ice box for bacterial analysis within two hours of collection. To isolate the enteric bacteria, the membrane filter technique was used. A volume of $60 \mathrm{ml}$ of the water sample was filtered through a sterile $47-\mathrm{mm}$-diameter grid-marked membrane filter with $0.45-\mu \mathrm{m}$ pores [14]. The membrane filters 
were placed on the surface of EMB agar plates for the isolation of enteric bacteria. MacConkey agar plates are used to differentiate both lactose and non-lactose fermenters bacterial isolates. The plates were incubated for 24 hours at $37^{\circ} \mathrm{C}$.

\subsection{Collection of Chicken Feces Specimens}

Twenty-seven specimens of chicken feces were sampled randomly each week from a farm located in eastern Baghdad. A total of $10 \mathrm{~g}$ of each sample was diluted in $90 \mathrm{ml}$ of sterile normal saline $(0.85 \% \mathrm{NaCl})$ and homogenized. Then, $10 \mu \mathrm{l}$ was placed on the surface of EMB agar plates and MacConkey agar. The plates were incubated for 24 hours at $37^{\circ} \mathrm{C}$ [15].

\subsection{Collection of Agriculture Soil Samples}

Ten agriculture soil samples were collected randomly each week from a farm. A total of $10 \mathrm{~g}$ of each sample was diluted in $90 \mathrm{ml}$ of sterile normal saline. Then, $10 \mu \mathrm{l}$ of each sample was placed on the surface of EMB agar plates and MacConkey agar and incubated for $24 \mathrm{~h}$ at $37^{\circ} \mathrm{C}[16]$.

\subsection{Total Viable Count for Environmental Specimens}

A serial dilution was prepared in normal saline $(0.85 \% \mathrm{NaCl})$ and plated onto nutrient agar. The total viable count was determined using the pouring plate technique on nutrient agar and counting the colonies developed after incubation at $37^{\circ} \mathrm{C}$ for $24 \mathrm{~h}$ [17].

\subsection{Biochemical Tests}

Gram negative bacteria were isolated on their respective selective and differential media and were identified on the basis of culture characteristics, including Gram reaction and biochemical tests, MacConkey agar, EMB, IMViC, Urea, and Kligler Iron Agar [2]. The automatic identification system, Vitek 2 with GN card (Gram-negative fermenter and non-fermenter bacilli), was also used.

\subsection{Antibiotic Sensitivity Test}

The antibiotic susceptibility profile of the Gram-negative isolates was determined using the standard Kirby-Bauer disk diffusion method [18]. These antibiotics with their respective disk concentrations are as follows: B_lactam group, including amoxicillin $(25 \mu \mathrm{g})$, ampicillin $(25 \mu \mathrm{g})$, ceftriaxone $(10 \mu \mathrm{g})$, ceftazidime $(10 \mu \mathrm{g})$, and cefepime (30 $\mu \mathrm{g})$; aminoglycosides group, including amikacin $(10 \mu \mathrm{g})$, gentamycin $(10 \mu \mathrm{g})$, and tobramycin (10 $\mu \mathrm{g})$; carbapenems group, including imipenem $(10 \mu \mathrm{g})$ and meropenem $(10 \mu \mathrm{g})$; monobactam group, including gaztreonam (30 $\mu \mathrm{g})$; quinolones group, including ciprofloxacin $(10 \mu \mathrm{g})$ and levofloxacin $(5 \mu \mathrm{g})$; sulfonamide group, including trimethoprim + sulfamethoxazole $(25 \mu \mathrm{g})$; and others group, including nitrofurantoin $(100 \mu \mathrm{g})$. Bacterial culture suspension equivalents to 0.5 tube McFarland turbidity standards were spread on Muller-Hinton agar plates using sterile swabs and incubated aerobically at $37^{\circ} \mathrm{C}$ for 24 hours; then, the inhibition zone diameters around the antibiotic disks were measured. The results are expressed as susceptible or resistant according to the criteria recommended by the CLSI [19].

\section{Results and Discussion}

The water microbiological examination is used worldwide to monitor and control the quality and safety of various water types. The present results showed the total viable count (TVC) of water was $3.26 \times 10^{4} \mathrm{cfu} / \mathrm{ml}$ (Table 1). While Ibrahim et al. report the highest TVC values were obtained in the Tigris study area from August and September, ranging from 128 to $10,000 \mathrm{cfu} / \mathrm{ml}$ [20]. The reason is due to the domestic discharges which are among the important sources of pollution of the Tigris Sanitary waters. The TVC for soil was $125.69 \times 10^{4} \mathrm{cfu} / \mathrm{gram}$. (Table 1). A previous study in Egypt recorded that the TVC from agricultural soil ranged from $27 \times 10^{2}$ to $31 \times 10^{4}$ cfu/gm during the hot season [21]. On the other hand, the TVC for poultry feces was $639.43 \times 10^{4} \mathrm{cfu} / \mathrm{ml}$ (Table 1). Adeleke and Omafuvbe recorded the TVC for poultry feces ranged from $1.41 \times 10^{6}$ to $437 \times 10^{6} \mathrm{cfu} / \mathrm{gm}$ [22]. The total bacterial count of the water and soil was determined and was compared with total bacterial count of the animal feces gave a clear picture of the survival and the percentage of bacteria in environmental sample. 
The most common lactose-fermenter bacterial isolates from environmental specimens were Escherichia coli, comprising $54.6 \%$ of the total samples, followed by Klebsiella pneumoniain $32.8 \%$ of samples (Table 2). Common water microbiological indicators are used as a marker of risk to human health include total coliform, Escherichia coli, enterococci, Clostridium perfringens, and Pseudomonas aeruginosa [6] [7]. Gammaproteobacteria included Enterobacteriaceae comprising 3.5\% of 751 soil bacteria isolate [23]. Non-lactose fermenter, such as Pseudomonas spp., Chryseomonas luteola, Burkholderia cepacia, and Aeromonas hydrophila, are the most common bacteria in agricultural soil [21] [23]. Additionally, E. coli was the prevalent organism isolated from poultry feces [22]. Still E. coli and K. pneumoniae the prevalence lactose fermenters isolates from environmental sample (water and soil), and animal feces.

Clinical samples showed both Escherichia coli and Klebsiella pneumoniae as the most common species (Table 3). A total of 812 clinical specimens from hospitalized patients revealed that the primary bacterial species was E. coli from urine specimens, with Enterobacter spp. second and Klebsiella spp. sixth; however, in the blood cultures, Enterobacter spp. and E. coli were the fourth and fifth most common strains, respectively [24]. Other studies showed that the Gram negative bacteria Escherichia coli and Klebsiella pneumoniae were the most common uropathogenic bacteria causing UTIs [25] [26]. Chronic surgical site infections showed E. coli and Serratia spp. as the sixth and seventh most common organisms, respectively [27]. Gram-negative organisms do not typically reside in the dry environment of normal skin [28], although occasionally, moist intertriginous areas allow for the growth of Acinetobacter spp. Our study showed that Klebsiella pneumoniae isolates were the common species isolated from the sputum followed by Serratia marcescens. A sputum sample from a pulmonary disease patient in the intensive care unit showed Klebsiella pneumonia, Escherichia coli and Enterobacter cloacae as the third, fourth and sixth most common isolates, respectively [29]. The present study also showed that Escherichia coli and Klebsiella pneumonia are the most common lactose fermenter Enterobacteriaceae iso-

Table 1. Mean $\left(\times 10^{3}\right)$ of total bacterial counts for environmental specimens.

\begin{tabular}{ccc}
\hline No. & Environmental samples & Total count $\left(\times 10^{4}\right)$ cfu/ml or $\mathrm{g}$ \\
\hline 1 & Water & 3.26 \\
2 & Soil & 125.69 \\
3 & Chicken feces & 639.43 \\
\hline
\end{tabular}

Table 2. Bacterial species isolated from environmental specimens.

\begin{tabular}{cccc}
\hline No. & Species & Number/(\%) & Environmental specimens \\
\hline 1 & Escherichia coli & $35(54.6)$ & Water, chicken feces \\
2 & Klebsiella pneumoniae & $21(32.8)$ & Water, chicken feces \\
3 & K. oxytoca & $2(3.12)$ & Chicken feces \\
4 & Raoultella planticola & $1(1.5)$ & Water \\
5 & Chryseomonasluteola & $1(1.5)$ & Soil \\
6 & Burkholderia cepacia & $1(1.5)$ & Soil \\
7 & Aeromonas hydrophila & $1(1.5)$ & Soil \\
\hline
\end{tabular}

Table 3. Bacterial species isolated from clinical specimens.

\begin{tabular}{cccc}
\hline No. & Species & Number/(\%) & Clinical specimens \\
\hline 1 & Escherichia coli & $70(75.26)$ & Blood, urine, wound, pus \\
2 & Klebsiella pneumoniae & $14(15.05)$ & sputum \\
3 & Enterobacter aerogenes & $6(6.45)$ & Blood, urine \\
4 & Serratia marcescens & $2(2.15)$ & sputum \\
5 & Citrobacter freundii & $1(1.07)$ & wound \\
& Total & 93 & \\
\hline
\end{tabular}


lated from clinical and environmental specimens, demonstrating the importance of controlling the spread of both E. coli and Klebsiella pneumoniae and further study for virulence genetic marker.

Our study showed the antimicrobial resistance profiles for Gram negative lactose-fermenting bacteria. The most common bacterial speciesin environmental specimens was $E$. coli, and it was more multidrug resistant than clinical specimens. Furthermore, the multidrug resistance was evident for $\beta$-lactam drugs, aminoglycosides, monobactams, quinolones, sulfonamides and nitrofurantoin (Figure 1). Klebsiella pneumonia was the second most common species with resistance to multiple antibiotics from six antibiotic groups, mainly for clinical isolates (Figure 2). However, the carbapenems group, including imipenem and meropenem, remain the drugs of choice for treatment against pathogenic bacteria. The high sensitivity of the bacterial isolates to the mentioned antibiotics could be related to less frequent usage of these drugs for therapeutic purposes, therefore reducing the chance for resistance to develop.

Figure 3 displays the antibiotic activity for all bacterial species; however, the carbapenem group remains the most effective drugs. The use of antibiotics has changed the natural evolution of bacteria by reducing susceptible pathogenic populations and increasing resistant populations [30]. Large amounts of antibiotics are used for hu-

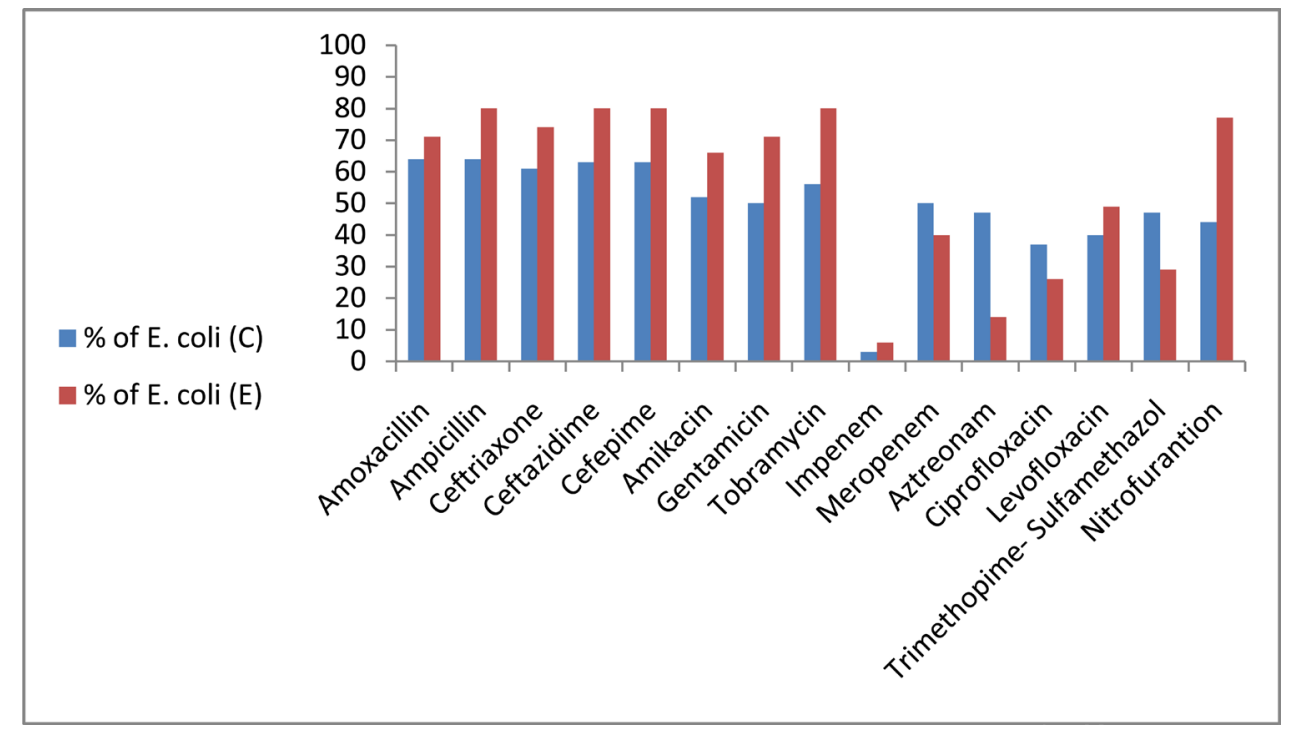

Figure 1. The percentage of antimicrobial resistance patterns of $E$. coli isolates (C: clinical specimens, E: environmental specimens).

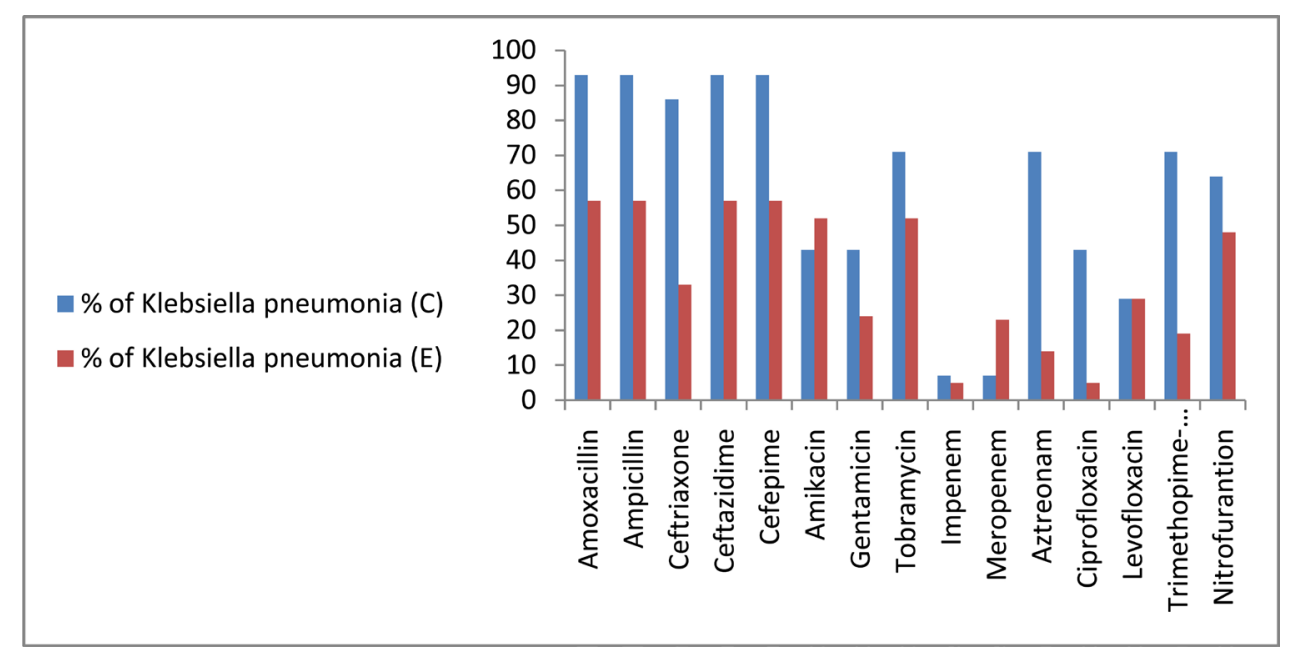

Figure 2. The percentage of antimicrobial resistance patterns of $K$. pneumoniae isolates (C: clinical specimens, E: environmental specimens). 


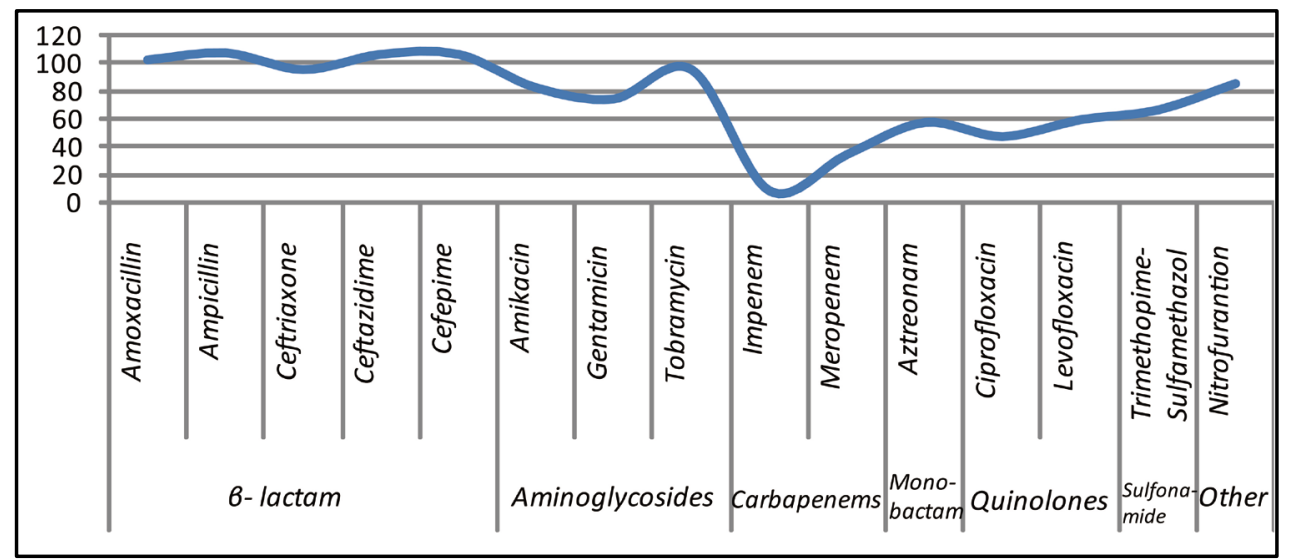

Figure 3. Comparison of antibiotic groups.

man therapy, as well as for farm animals and fish aquaculture, resulting in the selection of pathogenic bacteria resistant to multiple drugs [31]. Beta-lactam antibiotics are the largest and most commonly used group of antimicrobial agents worldwide [32]. A previous study demonstrated that these microorganisms utilize antibiotics as nutrients [33]. The genetic background of resistance mechanisms is diverse because they are present on chromosomes, plasmids, integrons and transposons [3]. Many studies suggest high levels of genetic flux between Gram-negative Enterobacteriaceae [34] that may favor plasmid exchange between Enterobacteriaceae members. Based on the results obtained in the present study, it is possible to conclude that the resistance for B-lactam antibiotic is a major problem in our community.

\section{Conclusion and Recommendations}

In conclusion, the most common lactose fermenter Enterobacteriaceae isolates from both the environmental and clinical samples were E. coli and Klebsiella pneumonia. The isolates exhibited multidrug resistance for B-lactam drugs (except carbapenems), aminoglycosides, monobactams, quinolones, sulfonamides and nitrofurantoin. Factors that may be associated with the transmission of resistant strains in the environment include poor hygiene, overcrowding, and antibiotic abuse. Future studies must collect more bacterial isolates from different sources in conjunction with genetic analysis. New strategies are also necessary to treat multidrug-resistant Gram negative bacteria.

\section{References}

[1] Brenner, D.J., Krieg, N.R., Staley, J.T., Garrity, G.M., Boone, D.R., De Vos, P., Goodefellow, M., Rainey, F.A. and Schleifer, K.H. (2005) Bergey’s. Manual of Systematic Bacteriology, 2nd Edition, Michigan State University, Springer, East Lansing.

[2] Forbes, B.A., Sahm, D.F., Weissfeld, A.S. and Bailey, W.R. (2007) Bailey \& Scott’s Diagnostic Microbiology. 12th Edition, Elsevier Mosby, St. Louis.

[3] Brooks, G.F., Carroll, K.C., Butel, J.S., Morse, S.A. and Mietzner, T.A. (2010) Medical Microbiology. Jawetz, Melnick and Adelbergs, 25th Edition, McGraw-Hill Companies, 213-219.

[4] Murray, P.R., Baron, E.J., Jorgensen, J.H., Pfaller, M.A. and Yolken, R.H. (2003) Enterobacteriaceae. Introduction and Identification. In: Farmer, III, J.J., Eds., Manual of Clinical Microbiology, Elsevier, Philadelphia, 647.

[5] Khan, F.R.M., Shukla, I. and Malik, A. (2011) A Novel Approach for Identification of Members of Enterobacteriaceae Isolated from Clinical Samples. Biology and Medicine, 3, 313-319.

[6] Barell, R.A.E., Hunter, P.R. and Nicholls, G. (2000) Microbiological Standards for Water and Their Relationship to Health Risk. Communicable Disease and Public Health, 3, 8-13.

[7] Fewtrell, La.B.J. (2001) Water Quality: Guidelines, Standards and Health. WHO, IWA Publishing, London.

[8] Hamilton, A.J., Stagnitti, F., Premier, R., Boland, A.M. and Hale, G. (2006) Quantitative Microbial Risk Assessment Models for Consumption of Raw Vegetables Irrigated with Reclaimed Water. Applied and Environmental Microbiology, 72, 3284-3290. http://dx.doi.org/10.1128/AEM.72.5.3284-3290.2006 
[9] Heaton, J.C. and Jones, K. (2008) Microbial Contamination of Fruit and Vegetables and the Behavior of Enteropathogens in the Phyllosphere: A Review. Journal of Applied Microbiology, 104, 613-626.

http://dx.doi.org/10.1111/j.1365-2672.2007.03587.x

[10] Levine, M. (1987) Escherichia coli That Cause Diarrhea: Enterotoxigenic, Enteropathognic, Enteroinvasive, Enterohemorrhagic and Enteroadherent. Biology and Medicine Journal, 155, 377-390.

[11] Kocsis, B. and Szabo, D. (2013) Antibiotic Resistance Mechanisms in Enterobacteriaceae. In: Mendez-Vilas, A., Ed., Microbial Pathogens and Strategies for Combating Them: Science, Technology and Education, Formatex Research Center, Badajoz, 251-257.

[12] Van der Bogaard, A.E. and Stobberingh, E.E. (2001) Recent Trend in Antibiotic Usage and Bacterial Resistance. Drugs, 65, 102-110.

[13] Scott, K.P. (2002) The Role of Conjugative Transposons in Spreading Antibiotic Resistance between Bacteria That Inhabit the Gastrointestinal Tract. Cell Molecular Life Science, 59, 2071-2082.

[14] Hleyn, J. and Bicknell, M. (2007) Microbiology Experiments: A Health Science Perspective. 5th Edition, McGraw-Hill Companies, Inc., New York.

[15] Bashar, T., Rahman, M., Rabbi, F.A., Noor, R. and Rahman, M.M. (2011) Enterotoxin Profiling and Antibiogram of Escherichia coli Isolated from Poultry Feces in Dhaka District of Bangladesh. Stamford Journal of Microbiology, 1, 51-57. http://dx.doi.org/10.3329/sjm.v1i1.9134

[16] Mujahid, T.Y., Siddiqui, K., Ahmed, R., Kazmi, S.U. and Ahmed, N. (2014) Isolation and Partial Characterization of Phosphate Solubilizing Bacteria Isolated from Soil and Marine Samples. Pakistan Journal of Pharmaceutical Sciences, 27, 1483-1490.

[17] Harley, J.P. and Prescott, L.M. (1996) Microbiology: Laboratory Exercises. 3rd Edition, McGraw-Hill Companies, New York.

[18] Bauer, A.W., Kirby, W.M.M., Sherris, J.C. and Truck, M. (1966) Antibiotic Susceptibility Testing by a Standardized Single Disk Method. American Journal of Clinical Pathology, 43, 493-496.

[19] CLSI (2012) Clinical and Laboratory Standards Institute. Performance Standards for Antimicrobial Susceptibility Testing; Twenty-Second Informational Supplement. CLSI Document M 100-S22. Clinical and Laboratory Standards Institute, Wayne.

[20] Ibrahim, I.A., Ismaeil, M.I. and Ibrahim, Y.A. (2013) Estimation of Validity Tigris River Water for Swimming in Baghdad City. Advances in Physics Theories and Applications, 18, 14-21.

[21] Bahig, A.E., Aly, E.A., Khaled, A.A. and Amel, K.A. (2008) Isolation, Characterization and Application of Bacterial Population from Agricultural Soil at Sohag Province, Egypt. Malaysian Journal of Microbiology, 4, 42-50.

[22] Adeleke, E.O. and Omafuvbe, B.O. (2011) Antibiotic Resistance of Aerobic Mesophilic Bacteria Isolated from Poultry Faeces. Research Journal of Microbiology, 6, 356-365. http://dx.doi.org/10.3923/jm.2011.356.365

[23] Sides, K.E. (2010) Agricultural Soil Bacteria; A Study of Collection, Cultivation, and Lysogeny. Master’s Thesis, University of Tennessee, Knoxville.

[24] Japoni, A., Vazin, A., Hamedi, M., Davarpanah, M.A., Abdolvahab, A. and Rafaatpour, N. (2009) Multidrug-Resistant Bacteria Isolated from Intensive-Care-Unit Patient Samples. Brazilian Journal of Infectious Diseases, 13, 118-122. http://dx.doi.org/10.1590/S1413-86702009000200009

[25] Behzadi, P., Behzadi, E., Yazdanbod, H., Aghapour, R., Cheshmeh, M.C. and Omran, D.S.A. (2010) Survey on Urinary Tract Infections Associated with the Three Most Common Uropathogenic Bacteria. Journal of Clinical Medicine, 5, 111-115.

[26] Beyene, G. and Tsegaye, W. (2011) Bacterial Uropathogens in Urinary Tract Infection and Antibiotic Suseptibility Pattern in Jimma University Specialized Hospital, South West Ethiopia. Ethiopian Journal of Health Sciences, 21, 141-146. http://dx.doi.org/10.4314/ejhs.v21i2.69055

[27] Wolcott, R.D., Gontcharov, V., Sun, Y., Zischakau, A. and Dowd, S.E. (2009) Bacterial Diversity in Surgicalsite Infections: Not Just Aerobiccocci Any More. Journal of Wound Care, 18, 317-323. http://dx.doi.org/10.12968/jowc.2009.18.8.43630

[28] Chiller, K., Selkin, A.S. and Murakawa, J.G. (2001) Skin Microorganism and Bacterial Infections of the Skin. Journal of Investigative Dermatology Symposium Proceedings, 3, 170-174. http://dx.doi.org/10.1046/j.0022-202x.2001.00043.x

[29] Cukic, V. (2013) The Most Common Detected Bacteria in Sputum of Patients with the Acute Exacerbation of COPD. Materia Socio Medica, 25, 226-229. http://dx.doi.org/10.5455/msm.2013.25.226-229

[30] Beceiro, A., Toms, M. and Bou, G. (2013) Antimicrobial Resistance and Virulence: A Successful or Deleterious Association in the Bacterial World? Clinical Microbiology Reviews, 26, 185-230. http://dx.doi.org/10.1128/CMR.00059-12

[31] Nikaido, H. (2009) Multidrug Resistance in Bacteria. Annual Review of Biochemistry, 78, 119-146. 
http://dx.doi.org/10.1146/annurev.biochem.78.082907.145923

[32] Tärnberg, M. (2012) Extended-Spectrum Beta-Lactamase Producing Enterobacteriaceae: Aspects on Detection, Epidemiology and Multi-Drug Resistance. Linköping University Medical Dissertations, No. 1300, LiU-Tryck, Linköping.

[33] Dantas, G., Sommer, M.O., Oluwasegun, R.D. and Church, G.M. (2008) Bacteria Subsisting on Antibiotics. Science, 320, 100-103. http://dx.doi.org/10.1126/science.1155157

[34] Stecher, B., Denzler, R.., Maier, L., Bernet, F., Sanders, M.J., Pickard, D.J., et al. (2012) Gut Inflammation Can Boost Horizontal Gene Transfer between Pathogenic and Commensal Enterobacteriaceae. Proceedings of the National Academy of Sciences of the United States of America, 109, 1269-1274. http://dx.doi.org/10.1073/pnas.1113246109 